\title{
The Development of a Model for Creative Writing Instruction for Mattayomsuksa Three Students (Grade 9)
}

\author{
Natsuchawirang Chaiyadejkamjorn ${ }^{1}$, Wimonrat Soonthonrojana ${ }^{1} \&$ Thanya Sangkhaphanthanon ${ }^{2}$ \\ ${ }^{1}$ Faculty of Education, Mahasarakham University, Thailand \\ ${ }^{2}$ Faculty of Human, Mahasarakham University, Thailand \\ Correspondence: Natsuchawirang Chaiyadejkamjorn, Faculty of Education, Mahasarakham University, Thailand. \\ Tel: 66-910-507-044. E-mail: natsucha.chai@gmail.com
}

Received: September 22, 2016

doi:10.5539/ies.v10n3p227

\author{
Accepted: October 25, $2016 \quad$ Online Published: February 27, 2017 \\ URL: https://doi.org/10.5539/ies.v10n3p227
}

\begin{abstract}
The research aimed to construct an instructional model for creative writing for Mattayomsueksa Three students (Grade 9), to develop the model according to a criterion of 80/80, and to examine the results of the model in use. The research methodology consisted of three phases: phase one studied the current states, problems and needs for teaching and learning Thai language; phase two constructed a model for creative-writing instruction; phase three explored the results of the model in use. The 83 samples were Mattayomsueksa Three students of Suranarai School, Mabkradvidaya School, Don Numsai School and Ban Koksawai School under the jurisdiction of the Office of Nakorn Ratchasima Primary Education Service Area 5 in the second semester of the academic year 2014. The subjects were derived by a multicluster random sampling. The research findings were as follows: 1 . The instructional model for creative writing was composed of six components: principles and basic concepts and theories, objectives, teaching steps, social system, principles of response, and support system. Teaching consisted of five steps: P1 (Planning), 2) P2 (Perception), 3) P3 (Performing), 4) P4 (Processing), 5) P5 (Production). Quality was at the highest level $(X=4.94)$. 2. The model for creative-writing instruction for Mattayomsueksa Three students as developed by the researcher had an efficiency equivalent to $81.17 / 80.26$, which was higher than the set criterion of 80/80. 3. The results of the use of the model were as follows: 3.1 Mattayomsueksa Three students who learned via the creative-writing model had a higher ability at a statistical significance of .05 .3 .2 The students of Suranarai School, Mabkradvidaya School, Don Namsai School and Koksawai had a satisfaction with the model in the study at $4.78,4.70,4.72$, and 4.69 respectively.
\end{abstract}

Key Words: development of learning and teaching model, creative writing

\section{Introduction}

Creative writing has become an integral part of daily life. The major goal of writers is to communicate their ideas with the readers. To achieve their goal, they are required to be skillful writers in that they need to use their unique imagination and innovative ideas in writing. Their writing styles should differ from other writers and present contents or ideas in a unique way to attract the readers (Surasith, 1998). Creative writing instruction is intended to help learners to better present or convey their imaginative writing ability compared to other kinds of writing. Students who have more opportunities to practice creating writing are more skillful in writing than those who practice only specific formats of writing (Cheewaphan, 1990). Moreover, creative writing has both a direct and indirect impact upon learners. Creative writing provides practical ideas for the learners that they can apply in their daily lives. It requires them to use a more positive imagination or ideas in order to produce a desirable product. Mentally, this satisfaction increases the pleasure in his or her writing. Thus, teachers should create an inviting and relaxed classroom atmosphere to better support creative writing activities so that the students can enjoy writing and are free to write depending on their age, individual differences, and writing skills. The classroom environment should prevent students from becoming bored and encourage them to convey their ideas and present their own experiences in creative writing activities. Thus the activities would inspire them to write (Cheewaphan, 2004).

This study was conducted at rural schools in the National Educational Service Area 5 in the province of Nakhon Ratchasima, in the northeast of Thailand. It was in this context that the researcher implemented a needs assessment. This assessment used a survey which received responses from 381 ninth grade students and Thai 
language teachers. The survey results indicated that these ninth graders rated creative writing the "highest" in terms of the challenges or difficulties in writing. According to national evaluation results among students in the ninth grade, students in the NESA5 scored lower in Thai language content in the year 2013 than in the previous school year. The average score was $40.82 \%$, which did not meet the standards (NESA5, 2013). Furthermore, this result was also lower than the national average score. Based on the needs assessment results it was concluded that the root cause of the problem of Thai language writing proficiency was the lack of activities to support and promote effective creative writing instruction. Therefore, instructional activities to promote and encourage creative writing based on appropriate ages, and learner levels should take place in the classroom (Pueksawan, 1992). Chareanwongsak (2004) also found that the challenge in learning and teaching was because the classroom instruction did not support or pay more attention to the genres of writing assignments or tasks such as writing reports or essays. Student assessments consisted of multiple choice or true/false questions. As a result, this has impacted students' writing skills because writing needs to explain the writer's ideas and/or convince others, so objective assessments are quite inappropriate. Teachers should promote or provide an adequate amount of opportunities for students to practice their writing regularly. When writing is planned and expected as a part of daily classroom activities, the students would develop their writing skills and become better writers. On the other hand, teachers will need to change their teaching behaviors and integrate writing tasks as a high priority classroom activity. The teachers must also focus on student-centered instruction models and recognize that students need to learn and build their own knowledge themselves. It is also very important for students to participate in group classroom processes. Khammanee, (2011) agreed with this concept. Her study, using a constructivist model, found that the teacher's role was different from an old traditional instruction role. The teachers were no longer just lecturers controlling the learning process. Instead, she found that teachers need to cooperate with, facilitate, and assist students in their learning. Teaching and learning will need to change from the old model of merely giving and memorizing information to seeking information and building new knowledge.

With the rationales mentioned in this study, the researcher concluded that it was necessary to develop a usable creative writing instruction model for ninth grade level students in the Thai language. In order to do so, concepts and theories were analyzed with several theories included in this study: constructivism, Piaget's theory of cognitive development, the concept of scaffolding in instruction, theories of creativity, transformative theory, and collaborative learning theory. This study also included the instructional model as developed by Joyce \& Weil (2009). The goal was to find the most effective instruction model and effective classroom activities that would have the most impact on students' creative writing.

\section{Research Methodology}

The present work was research and development. The aims were to study the needs for the development of the teaching of creative writing and to develop a model for creative writing for Mattayomsukas Three students. The research phases can be shown in the figure below. 


\begin{tabular}{|c|c|c|}
\hline $\begin{array}{l}\text { Phase One } \\
\text { Context of the basic information of the instructional model }\end{array}$ & $\begin{array}{l}\text { Phase Two } \\
\text { Development of the } \\
\text { instructional model }\end{array}$ & $\begin{array}{l}\text { Phase Three } \\
\text { Effects of the application of the } \\
\text { instructional model }\end{array}$ \\
\hline $\begin{array}{l}\text { 1. Survey of current states and needs of students and teachers of the } \\
\text { educational opportunity expansion schools } \\
\text { 2. Study of concepts, theories, documents and related research: } \\
2.1 \text { Constructivism } \\
\text { 2.2 Piaget's intellectual development theory } \\
\text { 2.3 Scaffolding } \\
\text { 2.5 Creative concepts } \\
\text { 2.5 Concepts of transferring knowledge } \\
\text { 2.6 Concepts of cooperative learning } \\
\text { 3. Conceptual framework was made and synthesized to create a learning } \\
\text { model according to Joyce and Well's concepts. The framework has six } \\
\text { parts: } \\
\text { 3.1 Concepts and theories of a model. } \\
\text { 3.2 Objectives } \\
\text { 3.3 Syntax } \\
\text { 3.4 Social support } \\
\text { 3.5 Principles of response } \\
\text { 3.6 Support system syntax has the following: } \\
\text { Step 1: planning } \\
\text { Step 2: perception } \\
\text { Step 3: performing } \\
\text { Step 4: processing } \\
\text { Step 5: production } \\
\text { 4. The outlined model is presented to five experts for their evaluation. }\end{array}$ & $\begin{array}{l}\text { The model was tried out } \\
\text { with } 32 \text { students by using } \\
\text { one group pretest-posttest } \\
\text { design }\end{array}$ & $\begin{array}{l}3.1 \text { The model was administered } \\
\text { on the subjects from } 4 \text { schools } \\
\text { by using one group pre-test and } \\
\text { post-test design. } \\
3.1 .1 \text { Study of the results of the } \\
\text { model by examining an } \\
\text { efficiency of the learning model } \\
\text { in four schools under study and } \\
\text { comparing the scores before and } \\
\text { after learning. } \\
3.1 .2 \text { Measurement of students' } \\
\text { satisfaction after their learning } \\
\text { by using the instructional model } \\
\text { in the study. }\end{array}$ \\
\hline
\end{tabular}

Figure 1. Steps of research and development of the instructional model

\section{Results}

The research was divided into three phases.

Phase one: a study of the needs for the development of a creative-writing model for Mattayomsuksa Three students

A study was conducted on the problems and needs for the development of the teaching and learning of teachers and students of the educational opportunity expansion schools. It was found that the needs for the development of the subjects were at a high level (3.76). On individual issues, they had a high level of need for the writing of creative advertisements (4.18), writing to express opinions and to tell stories (4.15), and writing to explain pictures at a high level (4.06).

Concepts and theories on creative writing can be summarized as follows: 1) constructivism explains that creative writing was an activity to encourage learners to become active and acquire knowledge based on the activity; 2) Piaget's intellectual development learning activities helped enhance learners' intellectual development as commensurate with age, experience, social transmission and balanced development processes; 3) creative ideas created the ideas of learners with the help of the intellectual process; 4) scaffolding: learning activities represented the process in which students learned things in a systematic way, a teacher served as a facilitator or helper so that learners can learn successfully and efficiently; 5) transmission and linking of knowledge: learners learned by linking their prior knowledge with newly acquired knowledge by virtue of learning activities; 6) cooperative learning: learning worked as a small group, had reciprocal interaction and mutual help to attain the set goal.

Phase two: Development of a model for creative writing for Mattayomsuksa Three students (Grade 9)

An instructional model for creative writing was made based on the concepts gained. The model had six components, each of which can be described as follows:

Component 1: Principles and Basic Foundation Theories. The following theories and concepts were studied: Constructivism, Piaget's Cognitive Development, Creative Learning Theory, Scaffolding, Transformative 
Learning Theory, and Collaborative Learning Theory.

Component 2: Learning goals in creative writing

Component 3: Syntax of the following five teaching steps using the five Ps: (1) Planning (P1) or the pre-writing stage to encourage students to plan or organize their ideas before they write. Teachers need to prepare data, information, materials, and activities about the writing topics; (2) Perception (P2) is the step for creating experiences that connect to learning perception and organize ideas to promote and support students' creative writing; (3) Performing (P3) expands ideas or practice writing by each student in the working group using information from step 2 to organize ideas and name the title based on the content; (4) Processing (P4) is the evaluation process after writing. Students present their writing to the entire class and receive feedback from teacher and classmates. This feedback can consist of pros and cons so that students can improve their writing assignments;(5) Production (P5) is the creation of a new piece of writing using individual imagination and conducting self-evaluation in the creative writing process.

Component 4: Social system. This emphasizes the instructor's role as a guide, facilitator, advisor, or supporter. The goal is to encourage learners to practice creative writing by providing examples and collaborative learning. This supporting role helps the learners interact with each other. The role of the learners is to practice writing, participate in learning activities, present the complete work to the class to receive feedback, and correct changes in order to complete the final creative writing process.

Component 5: Responsive principle. Learners collaborate by participating in learning activities while teachers act as the supporters to encourage, guide, and consult in the planning and creative writing processes. When the learners complete their work, the teachers should give them compliments and praise as a good example for other groups.

Component 6: Support system for learning, sources and experience exchange.

The model for creative writing in the study as examined by the experts was found to be suitable at the highest level.

The model was tried out with 32 Mattayomsuksa Three students of Ban Koksawai, TamonSai-oh in Nontai of Nakorn Ratchasima Province in the academic year 2014. It was found that in writing on floods, students were not familiar with group learning: a teacher had to step in to explain what they were to do. In writing on accidents, students became more active and could work more comfortably. In writing on advertisements, students were more motivated to learn; however, it was important to use media suitable for the age and development of learners; they should be exposed to the ads on TV and the Internet. In writing on moral issues, it was found that students paid more attention in learning. Moreover, social media were required to motivate them. In writing prose to describe pictures, students became more excited and motivated to learn. In writing on an imaginative story, it was necessary to use the media and events that could interest learners. Based on the trial, the effectiveness of the pilot instructional model results are shown in Table 1.

Table 1. The effectiveness of the pilot instructional model

\begin{tabular}{lcclc}
\hline Student Performance & Score & $\bar{X}$ & S.D. & Average Score Percentage \\
\hline Effectiveness of the Process (E1) & 150 & 121.5 & 3.09 & 81.17 \\
Effectiveness of the Results (E2) & 60 & 48.16 & 1.39 & 80.26 \\
Effectiveness of the Instructional Model (E1/E2) $=81.17 / 80.26$ & \\
\hline
\end{tabular}

Phase three: Study of the effects of the instructional model for creative writing in the study

Effectiveness of the instructional model for creative writing for Mattayomsuksa Three students was equivalent to $81.17 / 80.26$ as shown in table below.

Table 2. The effectiveness of an instructional model for creative writing in four sample schools $(\mathrm{N}=83)$

\begin{tabular}{lllll}
\hline Student Performance & Score & $\bar{X}$ & S.D. & Average Score Percentage \\
\hline Effectiveness of the Process (E1) & 150 & 122.60 & 3.24 & 81.73 \\
Effectiveness of the Results (E2) & 60 & 48.35 & 1.69 & 80.58 \\
Effectiveness of the Instructional Model (E1/E2)=81.73/80.58) \\
\hline
\end{tabular}


The students in the study who learned through the model for creative writing had a higher competence in writing than before with a statistical significance of.05 in all four schools under study.

The students in the study who learned through the model in question had a satisfaction at the highest level as shown in Table 3.

Table 3. Students' satisfaction towards learning through a model for creative writing in four schools

\begin{tabular}{llcc}
\hline No & Item & $\bar{X}$ & S.D. \\
\hline 1 & Creative writing is interesting to me. & 4.67 & 0.66 \\
2 & I feel satisfied to be able to write on various incidents. & 4.77 & 0.50 \\
3 & I love writing on goods ads. & 4.69 & 0.56 \\
4 & I am happy to be able to write a moral tale. & 4.76 & 0.58 \\
5 & I enjoy writing a poem to describe pictures. & 4.76 & 0.58 \\
6 & I am proud of myself to be able to write an imaginative story. & 4.71 & 0.67 \\
7 & I like to take part in a creative writing activity. & 4.75 & 0.54 \\
8 & I like to take part in a creative activity as it creates skills for me. & 4.66 & 0.70 \\
9 & I like to take part in the activity as there is a good model. & 4.73 & 0.56 \\
10 & I am proud of myself to have successfully created the writing. & 4.73 & 0.56 \\
Total & 4.72 & 0.59 \\
\hline
\end{tabular}

From Table 3, the students in the study were satisfied with the instructional model for creative writing at the highest level, which was equivalent to 4.72 .

\section{Discussion}

\subsection{Study on Needs for the Instructional Model}

The researcher studied current problems and needs to improve the instructional context for both students and teachers in the selected schools focusing on instruction in writing in the Thai language. The study results found that teachers and students had "high" needs to improve in Thai language instruction content in all elements. However, advertisement writing was one of the highest needs (mean $=4.18$ ). Writing a moral story was ranked next (mean $=4.15)$, then followed by imaginative writing at third $($ mean $=4.09)$, and finally, writing a poem to describe pictures was ranked last (mean $=4.06$ ). The needs assessment results were used to plan/design 10 ten lesson plans based on learners' age and developmental appropriateness.

The relevant concepts and theories on creative writing can be summarized as follows. 1) constructivism explains that creative writing was an activity to encourage learners to become active and acquire knowledge based on the activity; 2) Piaget's intellectual development learning activities helped enhance learners' intellectual development as commensurate with age, experience, social transmission and balanced development processes; 3 ) creative ideas created the ideas of learners with the help of the intellectual process; 4) scaffolding: learning activities represented the process in which students learned things in a systematic way, a teacher served as a facilitator or helper so that learners can learn successfully and efficiently; 5) transmission and linking of knowledge: learners learned by linking their prior knowledge with newly acquired knowledge by virtue of learning activities; 6) cooperative learning: learning worked as a small group, had reciprocal interaction and mutual help to attain the set goal.

\subsection{Development of a Quality Instructional Model}

Based on the concepts and theories studied, the instructional model acquired consisted of six components: 1) principles and basic theories, 2) objectives, 3) syntax, 4) social system, 5) principles of response, and 6) support system (Joyce \& Well, 2009, pp. 13-15). Joyce and Well explained that 1) the source of the model was an indicator of objectives, contents, and steps; 2) concepts and theories were the bases of the model; 3) objectives implied the expectation with regard to learners; 4) syntax indicated the methods and activities in various steps; 5) social system represented the relations between teachers and students; 6) support system represented an assistance given to students. Key procedures for using the model consisted of five steps: planning, perception, performing, processing and production.

The instructional model as developed by the researcher was found to be suitable at the highest level. The model in the study was systematically developed starting from studying the current states and problems in teaching Thai language, to synthesizing the components of teaching and learning and examining the model by five 
experts.

This instructional model for creative writing was used with 32 Mattayomsuksa Three students (Grade 9) of Ban Koksawai of TambonSai-oh in Nontai District of Nakorn Ratchasima Province, Thailand, in the academic year 2014. The purpose of an experimental use was to examine the possibility and conformity of the process and the steps of creating the model. In the first try-out according to five steps, students used 2.30 hours. That might be due to the fact that they were not familiar with the practice. Thus, advice and counseling were to be given.

After the experiment, the following things were found:

The model for instructional creative writing developed by the researcher had an efficiency equivalent to $81.17 / 80.26$. Students' average score during learning was 81.17 and their average score after learning was 80.26 . These results can be ascribed to the following reasons: The model was systematically developed. Its components were suitably determined and examined by five experts. In addition, the model was created based on the following concepts: To wit, constructivism (Khamanee, 2008:58) believed that learners had to be active and create elements of knowledge by themselves, learners' intellectual development, learners' creative ideas by using a cognitive process (Guilford, 1932:231), scaffolding, transmission of knowledge (Klausimier, 1985: 105). The finding was similar to that of Glazer (2009) who studied a group activity to learn writing. The study found that the group activity was positively influential on learners' attitude.

\subsection{Results of the Use of the Model for a Creative Writing}

An efficiency of the model in question was $81.17 / 80.26$. It can be interpreted that learners' average score during learning was 81.17 and after learning was 80.26. In addition, the model in the study was systematically developed and had appropriate components. The model was used with the samples. In a practical use, the model could be flexible and was suitable for a variety of activities. The activities used for a learning process should be in line with learners' intellectual development. To be able to write the ads, for example, the learners should be exposed to the real ads so that they are motivated and inspired before writing their own assignments. A teacher acted as a facilitator and helper for them. Thus, an appropriate model for a creative writing should be concerned with the development of learners' writing ability, including exercises in free writing. Attention should also be given to the relationship between learners and learners, learners and teachers. The result found was similar to that found by Glazer (2009:30-31) in that the teaching based on the group activity had an influence on learners' positive attitude.

A comparison of the scores of the students in the study before and after learning showed that Mattayomsuksa Three students who learned by using the model in the study had a higher writing ability with a statistical significance of .05 . The main factor contributing to this might be that various learning processes can motivate and inspire learners, due to absence of boredom and repetition. As a result, this type of situation is conducive to increased skills. Also, the learners could make good use of what they had learned in new contexts. Learners worked in a small group. They interacted and helped one another. Thanks to a variety of activities, students were not bored. Instead, they enjoyed learning. Consequently, their performance gradually increased. This finding was in accordance with the study by Giradi (2014) which found that an appropriate teaching model should be based on the idea that knowledge was derived from practice.

Considering the satisfaction of the subjects in the study, it was found that as regards the ten items, the students were satisfied with the model at a high level. The explanation was that the model for creative writing was focused on group work. A group's members worked together, which led to more responsibility. They were, hence, satisfied with what they were assigned. The finding was in accordance with the study by Galligan (2011) that examined cooperative teaching and its effectiveness and found that cooperative teaching was effective and could improve learners' achievement. Lanza (2009) conducted a study on the development of teaching by using the scaffolding method and found that an interaction among students could lead to improved learning and they could share their views and experiences in the classroom.

\section{Conclusion and Recommendations}

This research led to an instructional model for creative writing suitable for current situations, as well as practical and useful for teaching and learning processes.

\subsection{Recommendations for Application}

1) This instructional model for creative writing in the present study is focused on Mattayomsuksa Three students (Grade 9). It can be used at other levels, providing that attention is given to students' intellectual development and learning activities as are suitable for students' respective age. 
2) The contents used in the present research are based on the current states and needs for the development of teachers and students at grade 9 level of the educational opportunity expansion schools. Teachers can adapt and adjust the contents in line with any special and/or individual problems and needs by taking into account the components of the instructional model.

3) Activities and learning media should be interesting and varied in order to motivate and arouse student interest. These activities and media should be adjusted according to the individual school in question.

4) The instructional model can be used with different-sized classrooms. Learning activities should be carried out based on the aforementioned five steps of syntax/teaching.

5) A suitable duration for use of this model is two hours per-one lesson plan. Each step should be flexible and in accordance with the respective situations and conditions of the students in question.

\subsection{Recommendations for Further Research}

1) Further research on an instructional creative-writing model should be conducted in context of other subjects, such as mathematics and science.

2) Further research on an instructional creative-writing model should be conducted specifically for quick learners and slow learners.

3) A study should be also done on other variables like listening and speaking skills.

4) Research should be done on learning and teaching creative writing based on a wide variety of teaching theories.

\section{References}

Cheewapan, A. (2004). Creative Writing Activities for Elementary. Bangkok: ThaiWattanaPhanich

Galligan, G. (2011). Collaborative inquiry, teacher efficacy, and writing achievement at Lake Shore Elementary School (Ed.D. thesis, Arizona State University).

Girardi, T. A. (2014). It can be acquired and learned: Building a writer-centered pedagogical approach to creative writing (Ph.D. thesis, Indiana University of Pennsylvania).

Glazer, B. (2009). All for one and one for all: Peer writing groups in the developmental writing classroom (M.A. Thesis, Kean University).

Guilford. J. P. (1969). Intelligence: 1965 models. In E. P. Torrance, \& W. F. White (Eds.), Issues and Advances in Educational Psychology (p. 81). Ithaca, Illinois: F. E. Peacock.

Joyce, B., \& Weil, M. (1992). Models of Teaching (4th ed.). Massachusetts: Allyn \& Bacon.

Joyce, B., \& Weil, M. (2009). Models of Teaching. (8th ed.). Englewood Cliffs, NJ: Prentice-Hall.

Khammanee, T. (2011). The Art of Knowledge and Effective Learning Process. Bangkok: Chulalongkorn University Publishing.

Klausmeier, H. J. (1985). Educational Psychology (5th ed.). New York: Harper \& Row.

Lanza, K. C. (2009). Improving the teaching of writing through scaffolded lessons on author's craft (Ed.D. thesis, Rutgers State University of New Jersey, New Brunswick).

Nakon Ratchasima Office of Educational Service Area 5. (2013). Monitoring Team and Evaluation of Education, Student Proficiency Report of the Academic Year 2011-2013.

Peuksawan, B. (1992). Creative Writing Skill Development. Bangkok: Thai Wattana Phanich.

Surasith, P. (1998). Journaling Creative Writing. Bangkok: Seangdaow Publisher.

\section{Copyrights}

Copyright for this article is retained by the author(s), with first publication rights granted to the journal.

This is an open-access article distributed under the terms and conditions of the Creative Commons Attribution license (http://creativecommons.org/licenses/by/4.0/). 